\title{
PENGENALAN, PENYULUHAN, DAN PEMANTAUAN PENTINGNYA HIGIENE SANITASI TERHADAP PENYAKIT SALMONELLOSIS PADA KELOMPOK BUDIDAYA IKAN BANDENG DI SEGOROTAMBAK, SEDATI, SIDOARJO
}

\author{
Recognition, Counseling, and Monitoring the Importance of Higiene Sanitation \\ Against Salmonellosis Disease in Cultivator Breeders Milkfish \\ in Segorotambak, Sedati, Sidoarjo
}

\author{
Freshinta Jellia Wibisono $^{1)^{*}}$, Freegied Satriya Wibisono ${ }^{2,3)}$ \\ ${ }^{1}$ Dosen, Laboratorium Kesehatan Masyarakat Veteriner, Fakultas Kedokteran Hewan, Universitas \\ Wijaya Kusuma Surabaya \\ ${ }^{2}$ Penyuluh Perikanan, Dinas Perikanan Sidoarjo \\ ${ }^{3}$ Penyuluh Perikanan, Balai Pelatihan dan Penyuluhan Perikanan Banyuwangi
}

Article history

Received: Jul 1, 2020;

Accepted: Okt 20, 2020

* Corresponding author:

E-mail:

freshinta.uwks@gmail.com

DOI: https://doi.org/10.465

49/igkojei.v1i1.149

\section{ABSTRACT}

Sidoarjo Regency has the highest potential in milkfish aquaculture ponds. The maintenance of healthy milkfish requires clean and uncontaminated water and ponds, so sanitation efforts are needed in the management of milkfish cultivation. Milkfish is sensitive to Salmonella Spp. This service activity is carried out in several stages, namely 1) survei and filling in the questionnaire, 2) counseling activities, and 3) monitoring and evaluation. This community service was carried out to 3 groups of the milkfish cultivation community, namely the Mina Sentosa Segorotambak Group, Tumbuh Jaya Segorotambak, and Tumbuh Makmur Segorotambak Group. The results of the community service activities show that overall the milkfish farmers in Segorotambak Village have an understanding of higiene (77,78\%), sanitation (72,22\%), but overall respondents gave the answer that respondents did not know about salmonellosis (100\%). Salmonella spp. can survive in water contaminated with human or animal feces. The importance of awareness in maintaining higiene sanitation needs to be understood by milkfish pond farmers to prevent the incidence of salmonellosis. Communication, information, and education on the relationship between higiene sanitation and contamination against salmonellosis in the community is very necessary.

Keywords: Higiene; Milkfish; Sanitation; Salmonella spp; Salmonellosis

\section{ABSTRAK}

Kabupaten Sidoarjo memiliki potensi tertinggi pada tambak budidaya ikan bandeng. Pemeliharaan ikan bandeng yang sehat mensyaratkan air dan tambak yang bersih serta tidak tercemar, sehingga diperlukan upaya higiene sanitasi pada pengelolaan budidaya ikan bandeng. Ikan bandeng peka terhadap cemaran bakteri Salmonella Spp. Kegiatan pengabdian ini dilaksanakan melalui beberapa tahapan, yaitu 1) survei dan pengisian kuesioner, 2) kegiatan penyuluhan, dan 3) pemantauan evaluasi. Pengabdian masyarakat ini dilakukan pada 3 kelompok masyarakat budidaya bandeng yaitu Kelompok Mina Sentosa Segorotambak, Tumbuh Jaya Segorotambak, dan Tumbuh Makmur Segorotambak. Hasil kegiatan pengabdian menunjukkan bahwa secara keseluruhan pembudidaya tambak ikan bandeng di Desa Segorotambak, memiliki pemahaman terhadap higiene $(77,78 \%)$, sanitasi $(72,22 \%)$ namun secara keseluruhan responden memberikan jawaban bahwa responden belum mengetahui mengenai penyakit salmonellosis (100\%). Bakteri Salmonella spp. dapat bertahan pada air yang tercemar feses manusia atau hewan penderita. Pentingnya kesadaran dalam 
menjaga higiene sanitasi perlu dipahami oleh pembudidaya tambak ikan bandeng untuk mencegah kejadian penyakit salmonellosis. Komunikasi, informasi, dan edukasi pada mengenai hubungan higiene sanitasi dengan cemaran terhadap penyakit salmonellosis pada masyarakat sangat perlu untuk dilakukan.

Kata Kunci: Bandeng; Higiene; Sanitasi; Salmonella spp; Salmonellosis

\section{PENDAHULUAN}

Kabupaten Sidoarjo adalah salah satu kabupaten di Jawa Timur yang memiliki potensi pada pengembangan usaha budidaya tambak ikan bandeng, hal ini disebabkan karena tersedianya lahan tambak yang cukup dan ketersediaan air secara terus menerus. Bandeng merupakan salah satu komoditas perikanan air payau dan menjadi salah satu ikon dari kota Sidoarjo. Ikan bandeng merupakan jenis ikan konsumsi yang tidak asing bagi masyarakat. Budidaya ikan bandeng tidak menimbulkan pencemaran pada lingkungan sekitarnya. Pemeliharaan bandeng yang sehat mensyaratkan air dan tambak yang bersih serta tidak tercemar, sehingga diperlukan upaya higiene sanitasi pada pengelolaan budidaya tambak bandeng.

Higiene dan sanitasi merupakan dua hal yang berkaitan dan tidak dapat dipisahkan, namun memiliki cakupan yang berbeda. Higiene merupakan upaya pencegahan (preventive) yang berfokus pada upaya kesehatan manusia dan hewan, sedangkan sanitasi berfokus pada lingkungan sekitar (Menteri Kesehatan, 2003). Higiene sanitasi makanan adalah suatu upaya untuk menjaga atau mengendalikan faktor makanan, orang, tempat dan perlengkapannya yang dapat atau mungkin dapat menimbulkan penyakit atau gangguan kesehatan. Dalam pengelolaan makanan, terdapat 6 prinsip higiene sanitasi yang harus diperhatikan, yaitu: 1) Pemilihan bahan baku; 2) Penyimpanan bahan; 3) Pengolahan; 4) Pengangkutan; 5) Penyimpanan; dan 6) Penyajian makanan (Syahadah, 2018). Kondisi sanitasi higiene suatu usaha pangan menentukan keamanan produk (Domili, 2017; Nuryanti et al., 2017).

Perlindungan terhadap bahan baku dari bahaya bahan kimia, pertumbuhan mikroorganisme patogen dan pembentukan toksin selama transportasi dan penyimpanan bahan baku harus diperhatikan. Kerusakan bahan makanan dapat terjadi karena cemaran. Cemaran bakteri yang sering mengkontaminasi yaitu bakteri Salmonella spp. yang menyebabkan salmonellosis pada hewan dan manusia. Salmonellosis dikategorikan sebagai zoonosis yang penting dalam kesehatan masyarakat (Wibisono et al., 2020). Salmonellosis merupakan salah satu penyakit foodborne disease. Salmonella spp. merupakan bakteri Gram negatif yang berbentuk batang yang memiliki kemampuan adaptasi terhadap lingkungan sekitarnya. Bakteri Salmonella spp. dapat bertahan pada air yang tercemar feses manusia atau hewan penderita. Higiene sanitasi lingkungan sekitar tambak yang kurang bersih dapat menjadi faktor yang meningkatkan risiko cemaran Salmonella spp. pada ikan bandeng, Ikan bandeng peka terhadap cemaran. Cemaran Salmonella spp. pada ikan bandeng di pasar ikan Sidoarjo terdeteksi 20 sampel positif. dari total 42 sampel ikan Bandeng (Wibisono, 2017).

Kelompok budidaya ikan (Pokdakan) bandeng di Desa Segorotambak, Sedati, Sidoarjo merupakan kelompok yang terdiri dari beberapa petani tambak ikan bandeng di Desa Segorotambak, Sedati, Sidoarjo. Petani tambak di Desa Segorotambak ini pada umumnya memiliki tingkat pendidikan dan latar belakang yang berbeda beda, sehingga memiliki tingkat pemahaman yang bervariasi terhadap higiene sanitasi yang berhubungan dengan manajemen pengelolaan tambak bandeng. Pengabdian masyarakat terhadap pentingnya pemahaman higiene sanitasi tambak bandeng ini sangat perlu untuk dilakukan, berkaitan dengan manajemen budidaya ikan bandeng dan risiko penularan penyakit salmonellosis yang diakibatkan dari ceraman bakteri Salmonella sp. Dengan adanya pengabdian masyarakat ini diharapkan dapat meningkatkan pemahaman dan kesadaran petani tambak terhadap penting higiene sanitasi yang berhubungan dengan kesehatan masyarakat pada umumnya dan secara lebih khusus dapat mengurangi penyebaran penyakit salmonellosis pada petani tambak. 


\section{METODE}

Kegiatan pengabdian ini dilaksanakan melalui beberapa tahapan, yaitu 1) survei ke lokasi pengabdian dan pengisian kuesioner tentang tingkat pemahaman pembudidaya tambak terhadap hubungan higiene sanitasi terhadap penyakit salmonellosis di Desa Segorotambak, Kecamatan Sedati, Kabupaten Sidoarjo; 2) melakukan kegiatan penyuluhan mengenai pentingnya menjaga higiene sanitasi, sekaligus melakukan kegiatan pengamatan (observasi) lingkungan sekitar tambak; dan 3) melakukan pemantauan evaluasi, untuk mengevaluasi kegiatan dan mengevaluasi pemahaman masyarakat pembudidaya tambak ikan bandeng terhadap materi yang telah disampaikan.

Metode penerapan pengabdian yang dilakukan berupa penyuluhan mengenai kebersihan lingkungan sekitar tambak dan kebersihan diri masyarakat pembudidaya tambak ikan bandeng. Pemantauan dilakukan dengan mengamati tingkat kebersihan di lingkungan sekitar tambak serta wawancara secara langsung dengan pihak terkait untuk mengetahui tingkat kebersihan diri pada peternak tambak. Penyuluhan dilakukan pada peternak tambak dengan metode interaktif. Pengabdian masyarakat ini dilakukan pada 3 kelompok budidaya ikan bandeng yaitu Kelompok Mina Sentosa Segorotambak (19 orang anggota), Kelompok Tumbuh Jaya Segorotambak (17 orang anggota), dan Kelompok Tumbuh Makmur Segorotambak (18 orang anggota).

Kegiatan dilaksanakan secara bertahap. Tahap pertama dilakukan dengan pendekatan terhadap masyarakat dan pemantauan terhadap kebersihan lingkungan tambak. Tahap kedua dilakukan pemberian informasi dan pemahaman pada petani tambak pada untuk menjaga kebersihan. Tahap ketiga adalah pemantauan penerapan pola hidup bersih dan sehat dilingkungan masyarakat pembudidaya tambak ikan bandeng.

\section{HASIL DAN PEMBAHASAN}

\section{TINGKAT PEMAHAMAN MASYARAKAT TAMBAK BUDIDAYA IKAN BANDENG}

Desa Segorotambak merupakan salah satu desa binaan pada program higiene sanitasi masyarakat tambak bandeng yang berada di Kecamatan Sedati, Kabupaten Sidoarjo. Pembudidaya ikan bandeng di desa Segorotambak tergabung dalam 3 Pokdakan. Lokasi Desa Segorotambak berada di daerah Pesisir Juanda Sidoarjo, sehingga menjadi lokasi yang tepat untuk digunakan sebagai tambak bandeng, yang menggunakan air payau. Budidaya ikan bandeng menjadi mata pencaharian utama masyarakat Segorotambak. Berdasarkan survei lapangan, pembudidaya ikan bandeng didesa ini masih perlu diberikan pemahaman terhadap higiene sanitasi yang berhubungan dengan penyakit salmonellosis. Adapun kondisi dilapangan menunjukkan bahwa pembudidaya tambak belum memiliki kesadaran atau belum mampu membiasakan diri mencuci tangan sebelum dan sesudah melakukan aktivitas dari tambak bandeng. Hal ini berpengaruh pada cemaran Salmonella spp, yang kemungkinan terdapat di sekitar tambak. Oleh karena itu perlu diberikan penyuluhan dan pemahaman (Gambar 1) terhadap pentingnya menjaga higiene sanitasi pada saat melakukan aktivitas tambak, agar dapat menghindari kontaminasi cemaran bakteri Salmonella spp. Salmonellosis dapat menular secara langsung maupun secara tidak langsung. Penularan secara tidak langsung dapat terjadi melalui kontak dengan lingkungan sekitar atau dengan benda yang terkontaminasi. Distribusi Salmonella spp. sangat luas, tahan di lingkungan kering, dan dapat bertahan di air hingga beberapa bulan (Wibisono et al., 2020).

Hasil kuesioner (Tabel 1) menunjukkan bahwa secara keseluruhan pembudidaya tambak ikan bandeng di Desa Segorotambak, berjenis kelamin laki laki (100\%), hal ini sesuai dengan hasil yang menunjukkan bahwa pembudidaya tambak ikan bandeng merupakan pekerjaan utama (100\%). Budaya masyarakat menunjukkan bahwa laki laki merupakan pencari nafkah, dengan perempuan sebagai ibu rumah tangga yang melengkapi keperluan keluarga di rumah. Pembudidaya ternak di Desa Segorotambak memiliki rentang usia lebih dari 50 tahun sebanyak 59,25\%, rentang usia 40 49 tahun sebanyak 22,22\%, dan rentang usia 30 - 39 tahun sebanyak 18,53\%. Pembudidaya tambak ikan bandeng sebagai responden, pada kelompok usia diatas 30 tahun tergolong sebagai orang dewasa yang dianggap mengetahui mengenai kebiasaan dan keadaan lingkungan di sekitar tambak. 
Tingkat pendidikan pembudidaya tambak ikan bandeng mayoritas tamat SMA/SMA sebanyak 40,75\%, tamat SD sebanyak 25,92\%, tamat SMP sebanyak 20,37\%, dan tamat Perguruan Tinggi sebanyak $12,96 \%$. Tingkat pendidikan dapat mempengaruhi pola berpikir yang akan berpengaruh pada luasnya wawasan dan kemampuan sehingga akan meningkatkan pola pemeliharaan.
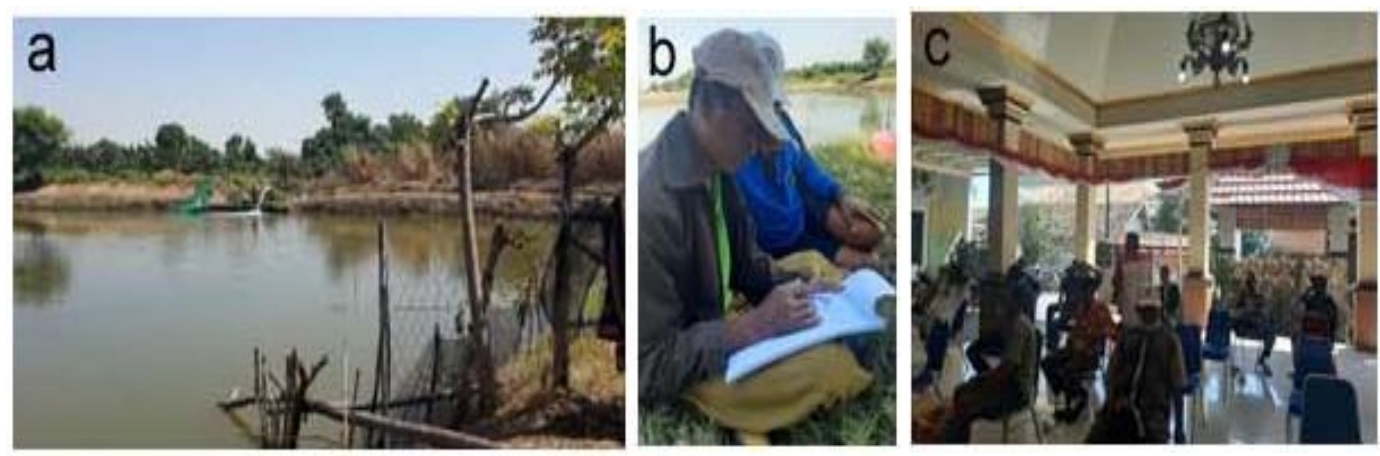

Gambar 1. Kegiatan pengabdian masyarakat. (a) Survei lapangan lokasi tambak (b) pendampingan dan pemantuan pemahaman higiene sanitasi (c) komunikasi, informasi, dan edukasi kepada petani tambak

Tabel 1. Distribusi Karakteristik Responden

\begin{tabular}{|c|c|c|c|}
\hline \multicolumn{2}{|c|}{ Karakteristik responden } & \multirow{2}{*}{$\begin{array}{l}\text { n } \\
54\end{array}$} & \multirow{2}{*}{$\begin{array}{c}\% \\
100 \%\end{array}$} \\
\hline Jenis kelamin & Laki laki & & \\
\hline & Perempuan & 0 & $0 \%$ \\
\hline \multirow{4}{*}{ Umur } & $20-29$ tahun & 0 & $0 \%$ \\
\hline & $30-39$ tahun & 10 & $18,53 \%$ \\
\hline & $40-49$ tahun & 12 & $22,22 \%$ \\
\hline & $>50$ tahun & 32 & $59,25 \%$ \\
\hline \multirow[t]{2}{*}{ Pekerjaan tambak } & Tetap / Utama & 54 & $100 \%$ \\
\hline & Sampingan & 0 & $0 \%$ \\
\hline \multirow{5}{*}{ Tingkat pendidikan } & Tidak tamat SD & 0 & $0 \%$ \\
\hline & Tamat SD & 14 & $25,92 \%$ \\
\hline & Tamat SMP & 11 & $20,37 \%$ \\
\hline & Tamat SMA / SMK & 22 & $40,75 \%$ \\
\hline & Tamat PT & 7 & $12,96 \%$ \\
\hline \multirow[t]{2}{*}{ Kepemilikan tambak } & Pemilik & 23 & $42,59 \%$ \\
\hline & Sewa & 31 & $57,41 \%$ \\
\hline
\end{tabular}

Keterangan: $\mathrm{n}=$ jumlah responden, $\%=$ persentase, $\mathrm{SD}=$ Sekolah Dasar, $\mathrm{SMP}=$ Sekolah Menengah Pertama, $\mathrm{SMA}=$ Sekolah Menengah Atas, SMK = Sekolah Menengah Kejuruhan, PT = Perguruan Tinggi

Pembudidaya tambak ikan bandeng di Desa Segorotambak (Tabel 2) pada umumnya memiliki pemahaman terhadap higiene $(77,78 \%)$, sanitasi $(72,22 \%)$ namun secara keseluruhan responden memberikan jawaban bahwa responden belum mengetahui mengenai penyakit salmonellosis (100\%). Hasil ini memperjelas kejadian dilapangan yang diamati pada saat observasi lapangan yang menunjukkan pembudidaya tambak ikan bandeng masih belum terbiasa menerapkan pola hidup higiene sanitasi. Pembudidaya memiliki pemahaman mengenai higiene sanitasi namun tidak mengetahui adanya penyakit salmonellosis yang berkaitan dengan higiene sanitasi, sehingga pembudidaya masih belum memiliki kesadaran untuk membiasakan diri menerapkan pola hidup higiene sanitasi. Hal ini menunjukkan bahwa diperlukan adanya pemahaman melalui penyuluhan mengenai penyakit salmonellosis yang berpotensi terjadi penularan melalui higiene sanitasi di sekitar tambak, Pentingnya kesadaran dalam menjaga higiene sanitasi perlu dipahami oleh pembudidaya tambak ikan bandeng untuk mencegah kejadian penyakit salmonellosis. Sanitasi diartikan sebagai usaha pencegahan penyakit dengan cara menghilangkan faktor-faktor lingkungan yang berkaitan dengan rantai perpindahan penyakit, sedangkan higiene adalah usaha pengendalian penyakit yang ditularkan melalui makanan (Domili, 2017; Sandra and Juhairiyah, 2015). Faktor 
kegagalan panen pada sektor budidaya perikanan disebabkan oleh penyakit, pencurian, dan kualitas air yang buruk serta bencana alam seperti banjir dan angin topan. Penyakit yang paling berpengaruh terhadap ikan budidaya adalah infeksi virus dan bakteri. Ikan yang sakit menyebabkan petani tambak mengalami kerugian karena harga jualnya menurun. Selain itu, sebaran penyakit karena virus dan bakteri ini menurunkan kualitas air (Azmi et al., 2016).

Tabel 2. Distribursi Pemahaman, Higiene, dan Sanitasi

\begin{tabular}{ccc}
\hline \multicolumn{1}{c}{ Variabel } & n & \% \\
\hline $\begin{array}{c}\text { Pemahaman penyakit salmonellosis } \\
\text { Baik }\end{array}$ Cukup & 0 & $0 \%$ \\
Kurang & 0 & $0 \%$ \\
Higiene & 54 & $100 \%$ \\
Baik & & \\
Cukup & 42 & $77,78 \%$ \\
Kurang & 3 & $5,56 \%$ \\
Sanitasi & 9 & $16,66 \%$ \\
Baik & & $72,22 \%$ \\
Cukup & 39 & $16,67 \%$ \\
Kurang & 9 & $11,11 \%$ \\
\hline Total & 6 & $100 \%$ \\
\hline
\end{tabular}

Keterangan : $\mathrm{n}=$ jumlah responden, $\%=$ persentase,

\section{POTENSI PENGEMBANGAN}

Faktor faktor higiene sanitasi pada masyarakat pembudidaya tambak ikan bandeng sangat ditentukan oleh beberapa faktor, yaitu penyuluh tambak yang berwenang, pemilik tambak budidaya ikan bandeng, pegawai pengelola harian tambak, masyarakat sekitar tambak budidaya ikan bandeng dalam menjaga kebersihan diri dan lingkungan. Namun hal tersebut seringkali tidak terjadi karena kurang perhatiannya berbagai pihak terkait dalam penerapan pola hidup bersih dan sehat serta biaya pemeliharaan sarana dan prasarana. Analisis kimia dan mikrobiologi produk sangat dibutuhkan untuk mengetahui kualitas bandeng yang dihasilkan. Analisis kimia untuk mengetahui komposisi nutrisi produk, sedangkan analisis mikrobiologi untuk mengetahui cemaran yang ada pada produk. Pengujian nutrisi produk ini diharapkan mampu meningkatkan daya jual bandeng yang dihasilkan (Anandito et al., 2019). Pengujian sanitasi air tambak dan pengujian sampel ikan bandeng secara berkala dapat diupayakan untuk meningkatkan daya jual ikan bandeng. Masyarakat atau konsumen akan merasa lebih aman untuk mengkonsumsi ikan bandeng yang berasal dari tambak ikan bandeng di Desa Segorotambak, Sedati, Sidoarjo.

Berdasarkan hasil pengamatan (observasi) lapangan dapat diketahui bahwa keberadaan tambak budidaya ikan bandeng di Desa Segorotambak, Kecamatan Sedati, Kabupaten Sidoarjo, dapat dikategorikan cukup dari standar, namun masih perlu dilakukan beberapa pembenahan untuk meningkatkan tingkat higiene sanitasi. Oleh karena itu perlu dilakukan pemahaman terhadap pelaku kepentingan untuk dapat mensosialisasikan kepada pihak terkait untuk selalu menjaga higiene sanitasi dan menjadikan pola hidup bersih menjadi suatu kebutuhan yang akan berdampak pada kesehatan serta kesejahteraan masyarakat tambak budidaya ikan bandeng. Pola hidup bersih pada higiene sanitasi dapat mengurangi faktor risiko tercemarnya bakteri Salmonella spp. pada ikan bandeng sehingga dapat menekan kejadian penyakit salmonellosis pada masyarakat. Pengembangan dapat dilakukan dengan pendampingan pola hidup bersih sebelum dan sesudah bekerja di tambak. Mengedukasi pentingnya saluran pembuangan dari tempat cuci tangan dan pembuangan limbah dari toilet umum di sekitar tambak.

\section{SOLUSI PENGEMBANGAN}

Upaya pengembangan program peningkatan pemahaman masyarakat dan upaya mengurangi 
faktor risiko cemaran salmonellosis serta mengubah perilaku higiene sanitasi pada peternak tambak yang lebih terarah, terencana terpadu dan berkesinambungan, Hasil kegiatan pengabdian diharapkan dapat mengurangi faktor risiko cemaran salmonellosis dan dapat mengubah perilaku higiene sanitasi pada peternak tambak. Untuk pencapaian tujuan tersebut maka kegiatan pengabdian dilaksanakan secara bertahap. Tahap pertama dilakukan dengan pendekatan terhadap masyarakat budidaya ikan bandeng dan pemantauan terhadap kebersihan lingkungan tambak. Tahap kedua dilakukan pemberian informasi dan pemahaman pada peternak untuk menjaga kebersihan. Tahap ketiga adalah pemantauan penerapan pola hidup bersih dan sehat dilingkungan masyarakat tambak budidaya ikan bandeng. Aspek sanitasi dan higiene yang sangat penting untuk diamati antara lain sanitasi dan higiene bahan baku, sanitasi dan higiene bahan tambahan, sanitasi dan higiene air, sanitasi dan higiene pekerja, sanitasi dan higiene ruang pengolahan dan lingkungan serta sanitasi dan higiene produk akhir (Domili, 2017). Penerapan konsep biosecurity menjadi solusi yang tepat bagi para petani tambak dalam menangani ancaman baik berupa penyakit dan hama pemangsa. Konsep Biosecurity yang diterapkan pada lahan tambak harus meliputi wilayah perairan, daratan dan udara di lingkungan lahan tambak (Dzakiy et al., 2017). Pemerintah sebagai agen perubahan dapat menerapkan kebijakan pemberdayaan masyarakat dengan tiga arah tujuan, yaitu enabling, empowering, dan protecting. Enabling maksudnya menciptakan suasana atau iklim yang memungkinkan potensi masyarakat untuk berkembang, sedangkan empowering, bertujuan untuk memperkuat potensi atau daya yang dimiliki oleh rakyat dengan menerapkan langkah-langkah nyata, yakni dengan menampung berbagai masukan dan menyediakan prasarana dan sarana yang diperlukan, sedangkan protecting, artinya melindungi dan membela kepentingan masyarakat lemah (Patra, 2017)..

\section{KESIMPULAN}

Berdasarkan hasil pemantauan pada kelompok masyarakat budidaya ikan tambak bandeng mengenai personal higiene dan sanitasi lingkungan termasuk dalam kategori cukup, hal ini dibuktikan dengan pemahaman mengenai higiene dan sanitasi. Namun demikian masih perlu dilakukan komunikasi, informasi, dan edukasi mengenai hubungannya dengan cemaran terhadap penyakit salmonellosis pada masyarakat.

\section{DAFTAR PUSTAKA}

Anandito RBK, Siswanti, Purnamayati L. 2019. Perbaikan Sanitasi dan Higiene Produk Bandeng Presto AR Putra Maju Jaya di Desa Tegal Arum, Mojosongo, Surakarta. Jurnal Kewirausahaan dan bisnis. 24:109-115.

Azmi F, Faisal TM, Suransyah A, Sinaga S, Firli A. 2016. Identifikasi Penyebab Kegagalan Panen Petani Tambak: Inventory, Dan Implikasi Biosecurity Perikanan Kota Langsa. Samudra Akuatika. 1:26-36.

Domili RS. 2017. Sanitasi dan higiene pada proses pembuatan rambak ikan buntal pisang (Tetraodon lunaris) di UKM Jaya Utama Kecamatan Mayangan Kota Probolinggo Jawa Timur. Jurnal Aquabis: 7:1-5. https://doi.org/10.31227/osf.io/c8axv

Dzakiy MA, Buchori A, Nurdyansyah F, Istiyaningsih R, Nindita V. 2017. Pembuatan desain kolam ikan bandeng berbasis konsep biosecurity bagi masyarakat petani tambak di pesisir Kabupaten Demak. Journal of Dedicators Community. 1:103-113.

Menteri Kesehatan. 2003. Pedoman persyaratan higiene sanitasi makanan jajanan. Indonesia. https://doi.org/10.16309/j.cnki.issn.1007-1776.2003.03.004

Nuryanti F, Junianto, Lili W. 2017. Analisis sanitasi dan higiene unit pengolahan ikan Kep.01/MEN/2007 (Studi Kasus Pengolahan Otak-Otak Bandeng Di Ukmp Juwita Food Bandung). Jurnal Perikanan dan Kelautan. 8:126.

Patra ADA. 2017. Pengolahan ikan bandeng (Chanos-chanos) cabut duri. RESONA : Jurnal Ilmiah Pengabdian Masyarakat 1, 26-33. https://doi.org/10.35906/jipm01.v1i1.244

Sandra L, Juhairiyah. 2015. Penerapan sanitasi dan hiygiene pada pembekuan ikan anggoli 
(Pristipomoides multidens) di CV Bee Jay Seafoods Probolinggo Jawa Timur. Samakia: Jurnal Ilmu Perikanan. 6:36-46.

Syahadah R. 2018. 6 Prinsip Higiene Sanitasi Yang Harus Diperhatikan. Indonesia Environment \& Energy Center. URL https://environment-indonesia.com/6-prinsip-higiene-sanitasi-yang-harusdiperhatikan/

Wibisono FJ. 2017. Deteksi Cemaran Salmonella sp. pada Ikan Bandeng (Chanos chanos) di Pasar Ikan Sidoarjo. Jurnal Kajian Veteriner: 5, 1-10.

Wibisono, F.M., Wibisono, F.J., Effendi, M.H., Plumeriastuti, H., Hidayatullah, A.R., Hartadi, E.B., Sofiana, E.D. 2020. A Review of Salmonellosis on Poultry Farms: Public Health Importance. Systematic Reviews in Pharmacy. 11:481-486. 